\title{
Enhanced production of xylanase by solid state fermentation using Trichoderma koeningi isolate: effect of pretreated agro-residues
}

\author{
Ramesh Bandikari • Vijayakumar Poondla • \\ Vijaya Sarathi Reddy Obulam
}

Received: 23 February 2014 / Accepted: 2 July 2014/ Published online: 30 July 2014

(C) The Author(s) 2014. This article is published with open access at Springerlink.com

\begin{abstract}
The main objective of this study was to isolate the fungal strain for enhanced production of xylanase using different agro-residues and fruit peels by solid state fermentation and its potentiality was tested on the pretreated corn cob. Fermentation was carried out with Trichoderma koeningi isolate using untreated and pretreated corn cob supplemented with pineapple peel powder showed higher production of xylanase $2,869.8 \pm 0.4(\mathrm{IU} / \mathrm{g})$ and extracellular protein $7.6 \pm 0.2(\mathrm{mg} / \mathrm{g})$ of corn cob, in the latter than the former yielding 1,347.2 $\pm 0.7(\mathrm{IU} / \mathrm{g})$ and $4.9 \pm 0.1$ $(\mathrm{mg} / \mathrm{g})$ of corn cob, respectively, at $\mathrm{pH} 6.5$ and incubation period for $96 \mathrm{~h}$. In the FT-IR spectrum, the bands at 1,155, 1,252 and $1,738 \mathrm{~cm}^{-1}$ had disappeared. This indicates the depolymerization of hemicellulose and the band at $1,053 \mathrm{~cm}^{-1}$ shows the presence of $\beta(1-4)$-xylan in the pretreated corn cobs. The pretreated biomass hydrolysed with a xylanase concentration of $14 \mathrm{U}$ and $6 \mathrm{~h}$ incubation showed mainly xylose and its oligosaccharides, which were quantified using HPLC. From the results we can conclude that pretreated energy-value and cheaply available agroresidues can be effectively used as substrates for the enhanced production of xylanase.
\end{abstract}

Keywords Agro-residues · Pretreatment - SSF . Xylanase $\cdot$ Xylose $\cdot$ Xylo-oligosaccharides

R. Bandikari · V. Poondla · V. S. R. Obulam $(\bowtie)$

Department of Biochemistry, Sri Venkateswara University,

Tirupati 517 502, India

e-mail: ovsreddy@yahoo.com

\section{Introduction}

Xylan is the second abundant polysaccharide after cellulose in plant cell walls and its structure is composed of $\beta$-1,4-linked-D-xylopyranose (heterogeneous) residues. It comprises 20-35\% dry weight of wood and agricultural wastes and is the major component of the hemicellulose portion. The industrial enzymes production is often limited by the cost of substrates for the cultivation of the microorganisms. The use of low cost substrates, such as agricultural wastes has been suggested as an alternative to reduce the production cost (Rajaram and Varma 1990). It represents a significant resource of renewable biomass which can be utilized as a substrate for the preparation of many useful products such as fuels, solvents and chemicals. For most of the bioconversion processes, xylan needs to be converted to xylose or xylo-oligosaccharides. Primary intention of any pretreatment is to change or depolymerize the structural and compositional inconvenience to hydrolysis and subsequent degradation takes place in order to increase the digestibility, enhance the rate of enzyme hydrolysis and increase yield of prospective products (Mosier et al. 2005).

Alkaline pretreatment is one of the best choices that has several benefits compared to other pretreatment processes including operation cost reduction, less degradation of holocellulose and formation of intermediate inhibitors for downstream processing (Dhillon et al. 2000). The principle of alkaline pretreatment mechanism is the degradation of ester bonds between the lignin structure and cleavage of glycosidic linkages in the lignocellulosic cell wall carbon matrix, which indicates the alteration of lignin structure and depolymerization of the lignin-hemicellulose complex, swelling and partial decrystallization of cellulose (Sun and Cheng 2002). 
Microbial xylanases are useful in many biotechnological industrial processes, such as pre-bleaching of kraft pulp (Bocchini et al. 2003), improving the digestibility of animal feed (Bedford and Classen 1992), juice clarification, and degumming of vegetal fibers such as jute, ramie and hemp (Kapoor et al. 2001). Xylanases are produced by a wide range of bacteria and fungi, including aerobes, anaerobes, mesophiles, thermopiles and extremophiles. Aerobic bacteria and fungi generally produce extracellular xylanases. The attack of the substrates is random and the bonds to be hydrolysed depend on the nature of substrate. During hydrolysis of xylan and arabinoxylan, the main products formed are xylo-oligosaccharides (Wong et al. 1988). Its complete hydrolysis is important in order to obtain, in higher yields, monosaccharides like D-xylose and L-arabinose are important, which could find applications in the food and fuel industries (Kim and Oh 2003). Enzymes from fungi such as the Trichoderma sp. deserve the most attention. Trichoderma sp. including $T$. reesei, T. harzianum and T. viride are well known as excellent producers of both xylanolytic and cellulolytic enzymes (Wong et al. 1988). Generally enzymes are produced by both SSF (solid state fermentation) and $\mathrm{SmF}$ (submerged fermentation), but SSF is natural like composting and ensiling.

The objective of the paper was to study the influence of "energy value" pretreated and untreated agro-waste substrates in different combinations on the improvement of the xylanase production by employing the Trichoderma sp. in SSF. The performance of the produced xylanase was also tested in the hydrolysis of pretreated natural biomass materials.

\section{Materials and methods}

Microorganism and culture media

Fifty fungal cultures were isolated and purified from sorghum litter collected from local agro-fields and maintained on sterile potato dextrose agar (PDA) slants at $4{ }^{\circ} \mathrm{C}$ and used as stock cultures. The isolates were identified on the basis of cultural characteristics and morphological features (Frazier and Westhoff 2008).

Inoculum preparation

A $100 \mathrm{~mL}$ of the broth containing $(\mathrm{g} / \mathrm{L})$ : glucose, 10.0 ; $\mathrm{KH}_{2} \mathrm{PO}_{4}, 2.0 ; \mathrm{MgSO}_{4} \cdot 7 \mathrm{H}_{2} 0,0.5 ; \mathrm{CaCl}_{2}, 0.2 ; \mathrm{NH}_{4} \mathrm{Cl}, 0.10$ and thiamine, 0.001 taken in $250 \mathrm{~mL}$ conical flask was sterilized at $121{ }^{\circ} \mathrm{C}$ for $15 \mathrm{~min}$, cooled to room temperature, inoculated with $T$. koeningi spore suspension and incubated at room temperature on a rotary shaker (120 rev $\min ^{-1}$ ) for 4 days to get a mycelial suspension as inoculum.
Preparation and analysis of agro-waste

The substrates wheat straw (WS), rice straw (RS), mustard straw (MS), cotton straw (CS), sorghum straw (SS) and corn cobs (CC) collected from the local agro-fields were washed with distilled water twice and dried at $70{ }^{\circ} \mathrm{C}$ for $12 \mathrm{~h}$ in an oven. The oven-dried substrates were milled and passed through $0.5 \mathrm{~mm}$ mesh and were collected in the polythene bags for further use. The substrates composition (cellulose, hemicellulose and lignin) was determined by the AOAC method (2005). Neutral detergent fiber (NDF) is the unit of measurement for the cellulose, hemicellulose and lignin content and represents most of the fiber or cell wall fractions in biomass. Acid detergent fiber (ADF) was determined sequentially using the residue left after NDF determination. Lignin content was determined as acid detergent lignin (ADL). The hemicellulose content was determined by subtracting ADF from NDF (Jung and Vogel 1992).

\section{Pretreatment of agro-waste}

The air dried and milled samples (WS, RS, MS, CS, SS and $\mathrm{CC})$ were used as raw material. The samples were then pretreated with 1.0, 1.5 and $2.0 \%(\mathrm{w} / \mathrm{w})$ of $\mathrm{NaOH}$ for $90 \mathrm{~h}$ at $90{ }^{\circ} \mathrm{C}$ and washed with distilled water till the washed water reaches $\mathrm{pH} 7.0$ and dried for $12 \mathrm{~h}$ at $80^{\circ} \mathrm{C}$. The pretreated agricultural substrate composition was determined by the AOAC method (2005). The reducing sugars released during the hydrolysis were estimated by using 3,5dinitrosalicylic acid (DNS) method (Miller 1959). The pentoses (xylose and arabinose) were estimated by the method of Khabarov et al. (2006).

Fruit peel powder preparation

Oven dried (at $70{ }^{\circ} \mathrm{C}$ for $7 \mathrm{~h}$ ) fruit peels of mausambi (MUP), pineapple (PP), mango (MP) and banana (BP) were collected, ground and milled into $0.5 \mathrm{~mm}$ mesh to make into powdery form. The collected peel powder was stored in polythene bags. The moisture, ash, crude protein, cellulose, hemicelluloses and lignin were determined by the procedure of AOAC method (2005). Total carbohydrate content was determined by the method of Dubois et al. (1956).

\section{Reducing sugars estimation}

This was carried out by using 3,5-dinitrosalicylic acid (DNS) method (Miller 1959). Sample (1 mL) was mixed with DNS $(3 \mathrm{~mL})$ and boiled for $10 \mathrm{~min}$. The optical density (OD) values were checked at $540 \mathrm{~nm}$ to measure 
the colour intensity. The actual values were obtained by extrapolating with a standard graph of glucose or xylose.

Total sugars estimation

To measure the total sugars in the hydrolysates, the phenol sulphuric acid method (Dubois et al. 1956) was used. Sample $(1 \mathrm{~mL})$ was mixed with $5 \%$ phenol $(1 \mathrm{~mL})$ and $96 \% \mathrm{H}_{2} \mathrm{SO}_{4}(5 \mathrm{~mL})$. The above mixture was kept for 10-15 min at room temperature. The OD values were checked at $470 \mathrm{~nm}$ to measure the colour intensity. The amount of sugars present in the sample solution was calculated using a standard graph. The absorbance corresponds to $0.1 \mathrm{~mL}$ of the test $=x \mathrm{mg}$ of glucose. $100 \mathrm{~mL}$ of the sample solution contains $x / 0.1 \times 100 \mathrm{mg}$ of glucose $=\%$ of total sugars present.

\section{Determination of protein}

The protein content in the culture filtrate was estimated by Folin-Ciocalteu reagent using bovine serum albumin (BSA) as standard (Lowry et al. 1951).

FT-IR analysis of pretreated corn cobs

The samples were prepared in the form of $\mathrm{KBr}$ (potassium bromide) discs, which were prepared by grinding $1 \mathrm{mg} /$ $100 \mathrm{mg} \mathrm{KBr}$ (FT-IR grade) in a vibratory ball mixture for $20 \mathrm{~s}$. The $13 \mathrm{~mm} \mathrm{KBr}$ discs were prepared under vacuum in a standard device under a pressure of $75 \mathrm{kN} \mathrm{cm}^{-2}$ for $2 \mathrm{~min}$. The spectra resolution was measured as $4 \mathrm{~cm}^{-1}$ and scanning range of $500-4,000 \mathrm{cmK}^{-1}$ by using PerkinElmer Spectrum 1 FT-IR.

\section{Enzyme production by SSF}

The SSF experiments were carried out by using different agricultural wastes (WS, RS, MS, CS, SS and CC) along with combinations of fruit byproducts (MUP, PP, MP and $\mathrm{BP}$ ) as solid material. $10 \mathrm{~g}$ of agro-residue (pretreated and untreated) and $5 \mathrm{~g}$ of byproducts was used in $500 \mathrm{~mL}$ Erlenmeyer flasks with basal medium of the following composition $(\mathrm{g} / \mathrm{L}): \mathrm{KH}_{2} \mathrm{PO}_{4}, \quad 1.6 ; \quad\left(\mathrm{NH}_{4}\right)_{2} \mathrm{SO}_{4}, \quad 1.4$; $\mathrm{CaCl}_{2} \cdot 2 \mathrm{H}_{2} \mathrm{O}, 0.4 ; \mathrm{MgSO}_{4} \cdot 7 \mathrm{H}_{2} \mathrm{O}, 0.6$; urea, 0.2 ; proteose peptone, 0.25 ; yeast extract, 0.2 ; moistened $60 \%$ by supplementing with mineral salt solution $\left[\mathrm{FeSO}_{4} \cdot 7 \mathrm{H}_{2} \mathrm{O}, 3\right.$; $\mathrm{MnSO}_{4} \cdot 7 \mathrm{H}_{2} \mathrm{O}, 4.6 ; \mathrm{ZnSO}_{4} \cdot 7 \mathrm{H}_{2} \mathrm{O}, 3.34 ; \mathrm{CoCl}_{2} \cdot 2 \mathrm{H}_{2} \mathrm{O}$, $1.5 \mathrm{mg} / \mathrm{L}$ ( $\mathrm{pH} 7.0)]$. The contents of the flasks were mixed properly and autoclaved at $121{ }^{\circ} \mathrm{C}$ for $15 \mathrm{~min}$ followed by cooling to room temperature and inoculated with $1 \mathrm{~mL}$ of T. koeningi $\left(1.0 \times 10^{5}\right.$ spores per $\left.\mathrm{mL}\right)$ spore suspension and incubated at room temperature for 7 days.
Enzyme harvesting

After the completion of the SSF, the solid culture medium was extracted using $100 \mathrm{~mL}$ of $50 \mathrm{mM}$ citrate buffer $\mathrm{pH}$ 5.0 , under shaking at $150 \mathrm{rpm}$ and $30{ }^{\circ} \mathrm{C}$ for $30 \mathrm{~min}$, for three times. Then the aggregated contents were centrifuged at $4{ }^{\circ} \mathrm{C}$ for $15 \mathrm{~min}$ and the supernatant was collected and stored at $4{ }^{\circ} \mathrm{C}$ to prevent loss of enzymatic activities.

\section{Xylanase assay}

Xylanase activity was measured by mixing $1.0 \mathrm{~mL}$ of $1 \%$ (w/v) birch wood xylan (Sigma, USA) as substrate prepared in $50 \mathrm{mM}$ sodium citrate buffer, $\mathrm{pH} 5.3$ with $0.1 \mathrm{~mL}$ of diluted enzyme and the mixture was incubated at $50{ }^{\circ} \mathrm{C}$ for $5 \mathrm{~min}$ (Bailey et al. 1992). The reaction was terminated by the adding of $1.5 \mathrm{~mL}$ of 3,5-dinitrosalicylic acid (DNS) reagent and the mixture was boiled for $5 \mathrm{~min}$ (Miller 1959) followed by cooling. The colour intensity was measured at $540 \mathrm{~nm}$ using UV-Visible Spectrophotometer. The amount of reducing sugars was measured quantitatively by using xylose as standard. One unit of xylanase activity was defined as the amount of enzyme producing $1 \mu \mathrm{mol}$ of equivalent to the xylose per min in the assay conditions.

\section{Cellulase assay}

The FPase, CMCase (Reese and Mandles 1963) and $\beta$-glucosidase (Berghem and Petterson 1973) activities (cellulase) were determined using the standard methods.

Optimization of pretreated biomass hydrolysis by xylanase

The pretreated biomass ( $3 \mathrm{~g})$ was suspended at $2 \%(\mathrm{w} / \mathrm{v})$ consistency of $0.05 \mathrm{mM}$ sodium citrate buffer, $\mathrm{pH} 5.3$ taken in $50 \mathrm{~mL}$ conical flasks and reacted with different doses of T. koeningi xylanase like 12.0, 14.0 and $16.0 \mathrm{U}$ for incubation periods of $2-8 \mathrm{~h}$ at $40{ }^{\circ} \mathrm{C}$ for determination of optimum conditions for hydrolysis.

\section{HPLC analysis of hydrolysed biomass}

The Dionex DX-600 series liquid chromatograph (HPLC) was used for the quantification of samples. The HPLC system consisted of an AS50 auto injector, degassing module, GS50 gradient pump, LC30 chromatography oven and UV detector. Chromatographic separation was achieved using a $150 \times 4.6 \mathrm{~mm}$ YMC carotenoid S-3 column (Milford). Gradient separations were carried out using aqueous $0.05 \%$ (v/v) phosphoric acid $(\mathrm{pH} 2-2.3)$ and water: acetonitrile (10:90) as the A and B solvents, respectively. Additional parameters were: injection volume, $25 \mu \mathrm{L}$, column 
temperature, $30{ }^{\circ} \mathrm{C}$, flow rate, $1 \mathrm{~mL} / \mathrm{min}$ and detection wavelength at $210 \mathrm{~nm}$. The xylose and xylo-oligosaccharides (xylobiose, xylotriose, xylotetraose, xylopentaose and xylohexaose) were eluted out with their gradients. Their retention time was compared with the external standards.

\section{Results and discussion}

FT-IR analysis of pretreated corn cob

The Fig. 1 shows the FT-IR spectrum of extracted xylan using $2 \% \mathrm{NaOH}$ pretreatment. The spectrum is compared with the standard library of lignocellulose (Liang and
Marchessault 1959). The pretreated corn cob spectrum band lengths were shown in the Table 1. It shows the dislocation or reduced the intensity of functional groups in the pretreated corn cobs, when compared to the standard lignocelluloses library. During the pretreatment some of the functional groups $\left(1,635,1,427\right.$ and $\left.896 \mathrm{~cm}^{-1}\right)$ were elevated and their peak assignment was in the Table 1. During $\mathrm{NaOH}$ pretreatment, the intra-molecular degradation of hemicellulose was represented by the decreased contents of functional groups and the disappearance of some bands in the pretreated spectrum compared with the standard spectrum. The peak at $1,252 \mathrm{~cm}^{-1}$ is indicative of $\mathrm{C}-\mathrm{O}$ streaching of syringe units and the peak at $1,155 \mathrm{~cm}^{-1}$ is characterized by the $\mathrm{C}-\mathrm{O}-\mathrm{C}$ vibration in

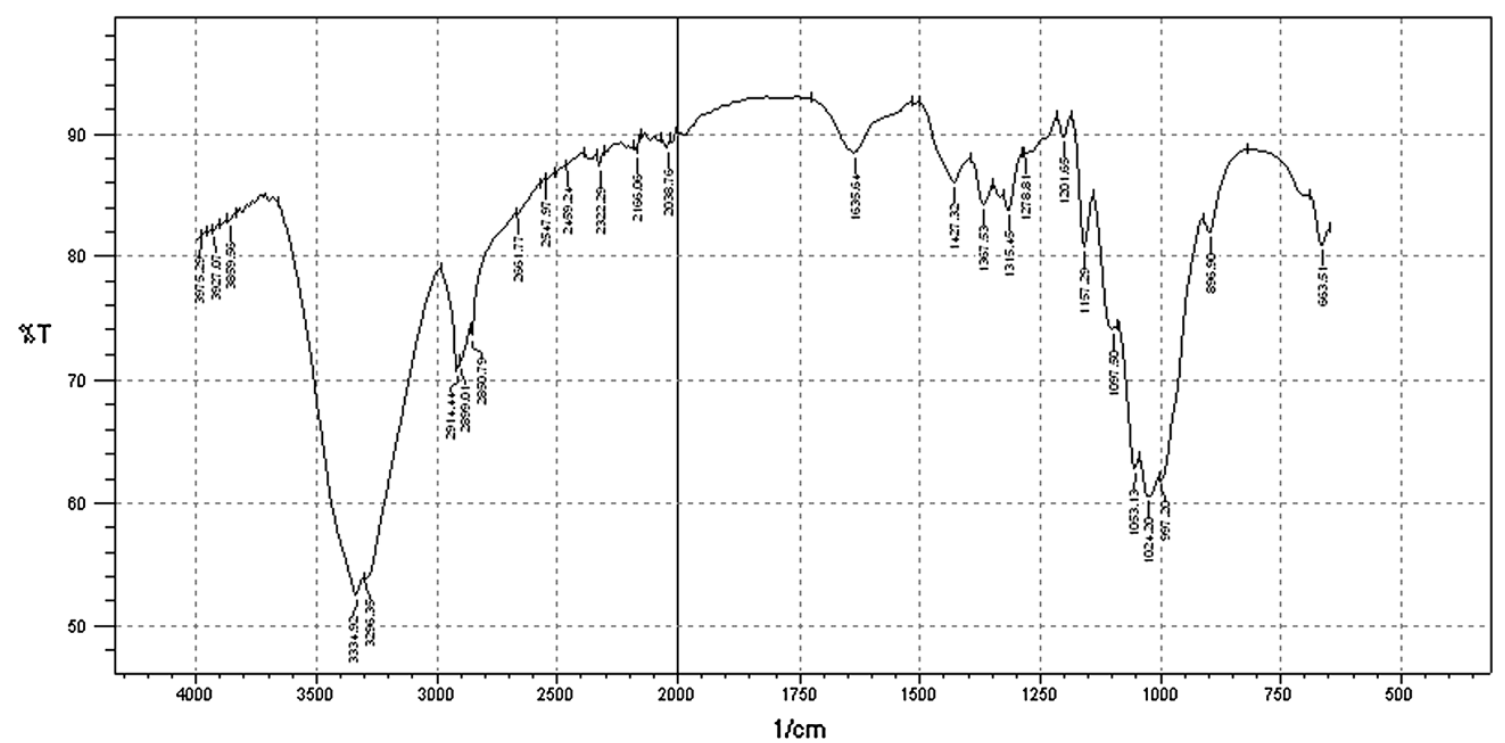

Fig. 1 FTIR spectrum of alkali pretreated corn cob with a scanning range of $500-4,000 \mathrm{~cm} \mathrm{~K}^{-1}$

Table 1 Assignment of the FT-IR bands of functional groups in pretreated corn cob

\begin{tabular}{|c|c|c|c|}
\hline $\begin{array}{l}\text { Wavelength number } \\
\text { (with dislocation) }\end{array}$ & $\begin{array}{l}\text { Functional } \\
\text { groups }\end{array}$ & Peak assignment & References \\
\hline $3,000-3,500 \mathrm{~cm}^{-1}$ & $\mathrm{O}-\mathrm{H}$ & $\begin{array}{l}\text { Stretching of alcohol and could be due to presence of adsorbed } \\
\text { water in the sample }\end{array}$ & $\begin{array}{l}\text { Owen and Thomas } \\
\text { (1989) }\end{array}$ \\
\hline $2,800-3,000 \mathrm{~cm}^{-1}$ & $\mathrm{C}-\mathrm{H}$ & $\begin{array}{l}\text { Energy absorbed due to } \mathrm{C}-\mathrm{H} \text { bonds stretching of methyl and } \\
\text { methylene (aliphatic and aromatic) groups }\end{array}$ & Ding et al. (2012) \\
\hline $2,000-2,350 \mathrm{~cm}^{-1}$ & $\mathrm{C} \equiv \mathrm{C}$ & Vibrations of $\mathrm{C} \equiv \mathrm{C}$ bonds due to the weak bands & Wilson et al. (2000) \\
\hline $1,635 \mathrm{~cm}^{-1}$ & $\mathrm{C}=\mathrm{O}$ & Carbonyl stretching associated with aromatic rings & Shi and Li (2012) \\
\hline $1,427 \mathrm{~cm}^{-1}$ & $-\mathrm{CH}_{2}$ & Plane-bending vibrations & $\begin{array}{l}\text { Schulz and Baranska } \\
\text { (2007) }\end{array}$ \\
\hline $1,367-1,315 \mathrm{~cm}^{-1}$ & $\mathrm{C}-\mathrm{O}$ and $\mathrm{C}-\mathrm{H}$ & $\begin{array}{l}\text { Attributed to weak } \mathrm{C}-\mathrm{O} \text { stretching and } \mathrm{C}-\mathrm{H} \text { symmetric and } \\
\text { asymmetric deformations }\end{array}$ & $\begin{array}{l}\text { Yu et al. (2007) } \\
\text { Sun et al. (2005) }\end{array}$ \\
\hline $1,207-1,157 \mathrm{~cm}^{-1}$ & $\mathrm{C}-\mathrm{O}$ & Due to weak $\mathrm{C}-\mathrm{O}$ stretching and glycosidic linkage & Robert et al. (2005) \\
\hline $1,100-1,000 \mathrm{~cm}^{-1}$ & $-\mathrm{C}-\mathrm{O}, \mathrm{C}=\mathrm{C}$ and $\mathrm{C}-\mathrm{C}-\mathrm{O}$ & $\begin{array}{l}\text { Vibrational stretching and can also be due to non-structural } \\
\text { CHO bending. }\end{array}$ & $\begin{array}{l}\text { Schulz and Baranska } \\
\text { (2007) }\end{array}$ \\
\hline $896 \mathrm{~cm}^{-1}$ & $\beta-1-4$ & $\beta-1-4$ linkage & Robert et al. (2005) \\
\hline
\end{tabular}


Table 2 Composition of untreated and treated (with $2 \% \mathrm{NaOH}$ ) biomass

\begin{tabular}{llrllllll}
\hline & Cellulose & \multicolumn{1}{l}{ Lignin } & Hemicellulose & Protein & Moisture & Ash & Total sugars & Reducing sugars \\
\hline Substrate untreated & & & & & & \\
W & $35.9 \pm 0.8$ & $6.25 \pm 0.2$ & $28.7 \pm 0.1$ & $3.77 \pm 0.4$ & $6.0 \pm 0.9$ & $8.2 \pm 0.7$ & ND & ND \\
R & $39.7 \pm 0.03$ & $8.9 \pm 0.8$ & $23.5 \pm 0.3$ & $2.75 \pm 0.8$ & $8.3 \pm 0.6$ & $6.8 \pm 1.4$ & ND & ND \\
M & $27.8 \pm 0.4$ & $5.2 \pm 0.6$ & $17.8 \pm 0.8$ & $2.03 \pm 0.3$ & $4.1 \pm 0.4$ & $5.5 \pm 1$ & ND & ND \\
C & $51.2 \pm 0.01$ & $10.4 \pm 0.6$ & $24.7 \pm 0.5$ & $2.19 \pm 0.7$ & $5.5 \pm 0.8$ & $5.6 \pm 0.7$ & ND & ND \\
S & $23.5 \pm 0.16$ & $5.8 \pm 0.9$ & $21.1 \pm 0.9$ & $1.84 \pm 0.5$ & $5.8 \pm 0.2$ & $4.3 \pm 0.4$ & ND & ND \\
CC & $42.8 \pm 0.06$ & $5.9 \pm 0.5$ & $37.2 \pm 0.3$ & $3.79 \pm 0.2$ & $7.0 \pm 0.4$ & $7.1 \pm 0.2$ & ND & ND \\
Substrate treated & & & & & & 0.6 \\
W & $39.3 \pm 0.2$ & $2.1 \pm 0.1$ & $19.4 \pm 0.6$ & $4.19 \pm 0.2$ & $4.1 \pm 0.8$ & $9.6 \pm 0.9$ & $0.67 \pm 0.4$ & $0.62 \pm 0.7$ \\
R & $42.2 \pm 0.02$ & $4.1 \pm 0.9$ & $16.5 \pm 0.3$ & $2.85 \pm 0.5$ & $5.0 \pm 1.5$ & $9.8 \pm 0.4$ & $0.48 \pm 0.7$ & $0.43 \pm 0.3$ \\
M & $30.2 \pm 0.2$ & $2.17 \pm 0.2$ & $10.7 \pm 0.7$ & $2.28 \pm 0.9$ & $1.8 \pm 0.6$ & $7.5 \pm 0.2$ & $0.57 \pm 0.3$ & $0.53 \pm 0.6$ \\
C & $61.7 \pm 0.6$ & $7.8 \pm 0.4$ & $15.6 \pm 0.8$ & $2.72 \pm 0.7$ & $3.3 \pm 0.9$ & $8.0 \pm 1.5$ & $0.77 \pm 0.2$ & $0.75 \pm 0.4$ \\
S & $26.8 \pm 0.04$ & $3.67 \pm 0.7$ & $11.1 \pm 0.5$ & $1.97 \pm 0.6$ & $3.7 \pm 0.6$ & $7.1 \pm 0.3$ & $0.45 \pm 0.7$ & $0.42 \pm 0.8$ \\
CC & $40.4 \pm 0.1$ & $2.56 \pm 0.4$ & $21.9 \pm 0.3$ & $4.17 \pm 0.3$ & $4.8 \pm 1.4$ & $9.8 \pm 0.8$ & $0.82 \pm 0.9$ & $0.78 \pm 0.2$ \\
\hline
\end{tabular}

Composition of untreated and treated biomass in percentage (\%)

Except moisture remaining all the composition of substrates were done based on dry weight basis \%

Values are mean of two replicates

$W$ wheat straw, $R$ rice straw, $M$ mustard straw, $C$ cotton straw, $S$ sorghum straw, $C C$ corn cobs, $N D$ not detected

Table 3 Composition of fruit peels

\begin{tabular}{lrrrrrrr}
\hline Substrates & \multicolumn{1}{c}{ Cellulose } & Hemicellulose & \multicolumn{1}{c}{ Lignin } & \multicolumn{1}{c}{ Protein } & Moisture & Ash & Total carbohydrates \\
\hline Mausambi peel & $14.96 \pm 0.01$ & $16.08 \pm 0.02$ & $8.89 \pm 0.02$ & $5.4 \pm 0.03$ & $5.3 \pm 0.05$ & $5.8 \pm 0.01$ & $14.24 \pm 0.06$ \\
Pineapple peel & $20.6 \pm 0.04$ & $27.23 \pm 0.05$ & $10.30 \pm 0.04$ & $8.7 \pm 0.02$ & $9.4 \pm 0.02$ & $3.9 \pm 0.03$ & $29.19 \pm 0.04$ \\
Mango peel & $13.2 \pm 0.03$ & $20.84 \pm 0.06$ & $7.73 \pm 0.01$ & $9.5 \pm 0.05$ & $7.3 \pm 0.05$ & $6.4 \pm 0.05$ & $20.73 \pm 0.06$ \\
Banana peel & $24.6 \pm 0.02$ & $13.46 \pm 0.01$ & $11.62 \pm 0.04$ & $6.02 \pm 0.03$ & $10.5 \pm 0.03$ & $4.2 \pm 0.02$ & $17.83 \pm 0.02$ \\
\hline
\end{tabular}

Except moisture remaining all the composition of substrates were done based on dry weight basis \%

Values are mean of two replicates

anomeric region of hemicellulose. The two bands were found disappeared, elucidating that the structure of hemicelluloses was changed after $\mathrm{NaOH}$ pretreatment, thus hemicellulose was degraded. Similarly the hemicellulose band appeared at $1,738 \mathrm{~cm}^{-1}$ for all original samples (Kumar et al. 2009). No hemicellulose band was observed after treatment of corn cobs, indicating that hemicellulose was depolymerised during the pretreatment process. The chemical composition analysis of biomass (Table 2) supports the FT-IR observations that the hemicellulose content of biomass decreased after pretreatment. The linear and branched (1-4)- $\beta$-xylans showed the main peak maximum at about $1,053 \mathrm{~cm}^{-1}$. It resembles that spectrum of pretreated corn cobs showed extraction of xylan and it is absent in the standard library. Lignin related bands in the spectrum were seen around 1,273, 1,518, 1,610 and $1,715 \mathrm{~cm}^{-1}$ (Kumar et al. 2009). The band at $1,518 \mathrm{~cm}^{-1}$ attributed to the $\mathrm{C}=\mathrm{C}$ of lignin, was observed in lignocelluloses. This spectrum did not show the $1,518 \mathrm{~cm}^{-1}$ band after pretreatment. No detection of an absorption band at $1,715 \mathrm{~cm}^{-1}$, due to the $\mathrm{C}=\mathrm{O}$ of the phenyl ester linkages between lignin and a hemicellulose had been cleaved by dilute alkali pretreatment. The typical adsorption of cellulose backbone at $1,635 \mathrm{~cm}^{-1}$, from the hydrogen bonded $\mathrm{OH}$ stretching at $3,000-4,000 \mathrm{~cm}^{-1}$, is due to the $\mathrm{H}$ bonded $\mathrm{OH}$ groups (at 3,334.92 $\mathrm{cm}^{-1}$ ) and the stretching frequency of the $-\mathrm{OH}$ as well as intramolecular and intermolecular hydrogen bonds (Richard 2002). The wide band between the 3,000 and $3,500 \mathrm{~cm}^{-1}$ was due to $\mathrm{OH}$ stretching vibrations of alcohols and phenols (Singh et al. 2005).

Composition of agro-residues and fruit peels

The cell wall components of agro-residue were different due to the variation in the chemical composition of 
agro-residues with plant species, tissue type and region within the cell wall and development stages of the cell wall (Carpita and Mc Cann 2000). The untreated Toona ciliate holocellulose and lignin was high: 72.56 and $21.45 \%$, when compared to pretreatment with $1 \% \mathrm{NaOH}$, it having the holocellulose 62.68 and lignin $15.45 \%$. Similarly the Pinus roxburghii holocellulose $(67.24 \%)$ and lignin $(26.40 \%)$ was high in untreated and in pretreatment the holocellulose $(58.54 \%)$ and lignin $(19.2 \%)$ was low (Kaushal et al. 2012). For pretreated substrates, a reduction in percentage of lignin components was observed along with the depolymerization of holocellulose. To identify the suitability of substrate for xylanase production under SSF conditions, the chemical composition of substrates was determined under standard experimental conditions. In the present study, the composition of structural agro-residues contained higher levels of cellulose, hemicellulose and lignin in the corn cobs and lower levels in the sorghum straw. High levels of moisture in rice straw, ash in wheat straw, protein in the corn cobs, simultaneously low levels of moisture in cotton straw, ash and protein contents in the sorghum straw was observed. During the pretreatment, some amount of total sugars was lost. This was high in case of corn cobs and low in case of sorghum straw (Table 2). Compared with acid processes, alkaline processes have less sugar degradation. Sodium, potassium, calcium and ammonium hydroxide are suitable alkaline pretreatment agents. Among the four alkaline agents, sodium hydroxide has been the most studied (Soto et al. 1994).

The proximate compositions of fruit peels are shown in Table 3. From the data it was observed that hemicellulose content was present in a significant quantity in all fruit peels followed by cellulose and lignin. It is clear that there was a relatively low level of lignin, which makes the fruit peels amenable to the utilization of fungal strains. The protein content was high in the mango peel and low in the mausambi peel. Li et al. (2010) reported relatively high amount of hemicellulose, cellulose and lower value of a lignin in citrus peel. According to studies of Chen and Wyman (1991) the carbohydrates stimulated the growth of fungi; in the present study, pineapple peel contained high amount of total carbohydrates $29.19 \pm 0.04 \%(\mathrm{w} / \mathrm{v})$ that served as growth of the fungi and production of xylanase in the medium. The total carbohydrate content is higher in pineapple peel and followed mango, banana and mausambi peel.

Effect of pretreatment on xylanase production

Kleinert and Barth (2008) reported that chemical pretreatment of lignocelluloses causes swelling leading to an increase in internal surface area, decrease in the degree of polymerization, separation of structural bonds between lignin and carbohydrates. In the present study, the agroresidues were pretreated with different concentrations (1.0, 1.5 and $2.0 \%) \mathrm{NaOH}$. The composition of plant cell mainly consisted of cellulose followed by hemicellulose (xylan), greater the hemicellulose more the depolymerization was occurred which was freely available to the growth of fungal strain and hence greater enzyme production. The $2 \% \mathrm{NaOH}$ pretreated agro-residues led to maximum xylanase enzyme production. Increased concentration of $\mathrm{NaOH}$ beyond $2 \%$ decreased the enzyme production. The pretreatment caused the removal of lignin effectively, while at the same time loosened the structure of lignin and hemicellulose. The internal structure of hemicellulose breakdown improved the porosity characteristic of substrate. A significant difference in enzyme activity and protein was observed with the change in alkali concentration and reached maximum $1,267.3 \pm 0.6 \mathrm{IU} / \mathrm{g}$ and $4.3 \pm 0.2 \mathrm{mg} / \mathrm{g}$, respectively in corn cobs by T. koeningi (Table 4). Most strains of the Trichoderma sp. are notable producers of extracellular enzymes including important plant cell-wall hydrolyzing enzymes such as xylanases (Biely 1985).

Enhancing the xylanase production using fruit peels powder

Currently, it could be considered as low cost strategy is the use of byproducts of industries as additional carbon source for the production of the enzymes. Villas-Boas et al. (2000) have used apple pomace for the production of xylanase by Candida utilis, whose cost was found to be comparatively low. Reddy et al. (2003) studied the xylanase production from Pleurotus sp., using banana wastes. Large scale production of xylanase using pure xylan is uneconomical because of its cost. Hence cheap fruit peels were used as source of carbon material. Different locally available fruit- peels were collected and supplemented with various agro-residues in SSF. Among all the fruit peels, the pineapple peel powder combined with corn cobs enhanced significantly xylanase $2,869.8 \pm 0.4 \mathrm{IU} / \mathrm{g}$ and protein $7.6 \pm 0.2 \mathrm{mg} / \mathrm{g}$, respectively (Table 4). Xylanase showed with maximal activity at $\mathrm{pH} 6.5$, there was less xylanase at $\mathrm{pH} 5$, and the activity was declined with increase in $\mathrm{pH}$ of 7.0-9.0 (Fig. 2). Gomes et al. (1992) reported that the maximal xylanase production obtained SSF conditions with $\mathrm{pH} 7.0$ which was near to the present result. The xylanase activity was low at $25{ }^{\circ} \mathrm{C}$ declined after $37^{\circ} \mathrm{C}$ and attained maximum activity at $37{ }^{\circ} \mathrm{C}$. The results of the present study was near to the to the results of Gupta et al. (2009) found $30{ }^{\circ} \mathrm{C}$ as optimum temperature for maximum xylanase production with wheat bran by Fusarium solani F7 respectively (Fig. 3). The loss of enzyme activity at high temperature is due to the denaturation and conformational changes. 
Table 4 Production of xylanase by untreated and pretreated biomass with different concentrations of $\mathrm{NaOH}$

\begin{tabular}{|c|c|c|c|c|c|c|c|c|}
\hline \multirow[t]{3}{*}{ Substrate (g) } & \multicolumn{4}{|c|}{ Xylanase (IU/g) } & \multicolumn{4}{|c|}{ Protein $(\mathrm{mg} / \mathrm{g})$} \\
\hline & \multirow[t]{2}{*}{ Untreated } & \multicolumn{3}{|l|}{ Pretreated } & \multirow[t]{2}{*}{ Untreated } & \multicolumn{3}{|l|}{ Pretreated } \\
\hline & & 1.0 & 1.5 & 2.0 & & 1.0 & 1.5 & 2.0 \\
\hline W & $580 \pm 0.8$ & $622.4 \pm 0.7$ & $678.2 \pm 0.2$ & $734.6 \pm 0.5$ & $3.1 \pm 0.1$ & $3.7 \pm 0.4$ & $3.8 \pm 0.2$ & $4.2 \pm 0.6$ \\
\hline $\mathrm{R}$ & $217.7 \pm 0.5$ & $222.6 \pm 0.4$ & $243.7 \pm 0.4$ & $278.6 \pm 0.8$ & $2.9 \pm 0.6$ & $1.1 \pm 0.5$ & $1.4 \pm 0.7$ & $1.9 \pm 0.4$ \\
\hline M & $156.3 \pm 0.9$ & $148.7 \pm 0.8$ & $156.5 \pm 0.9$ & $169.7 \pm 0.4$ & $2.1 \pm 0.2$ & $0.9 \pm 0.2$ & $0.9 \pm 0.3$ & $1.0 \pm 0.5$ \\
\hline $\mathrm{C}$ & $189.8 \pm 0.6$ & $196.5 \pm 0.3$ & $199.8 \pm 0.4$ & $217.7 \pm 0.2$ & $2.8 \pm 0.1$ & $1.0 \pm 0.7$ & $1.1 \pm 0.6$ & $1.2 \pm 0.3$ \\
\hline $\mathrm{S}$ & $169.9 \pm 0.7$ & $170.6 \pm 0.7$ & $182.9 \pm 0.8$ & $198.7 \pm 0.4$ & $1.9 \pm 0.7$ & $0.9 \pm 0.4$ & $1.0 \pm 0.1$ & $1.1 \pm 0.8$ \\
\hline $\mathrm{CC}$ & $810.7 \pm 0.1$ & $745.7 \pm 0.2$ & $778.8 \pm 0.7$ & $1267.3 \pm 0.6$ & $3.7 \pm 0.4$ & $4.3 \pm 0.2$ & $4.5 \pm 0.3$ & $4.5 \pm 0.2$ \\
\hline W+MUP & $520.6 \pm 0.4$ & $479.2 \pm 0.9$ & $538.6 \pm 0.6$ & $578.8 \pm 0.1$ & $2.6 \pm 0.8$ & $2.4 \pm 0.9$ & $2.7 \pm 0.2$ & $3.1 \pm 0.6$ \\
\hline R+MUP & $151.5 \pm 0.6$ & $172.8 \pm 0.4$ & $189.7 \pm 0.9$ & $196.9 \pm 0.8$ & $1.7 \pm 0.3$ & $0.9 \pm 0.4$ & $1.0 \pm 0.3$ & $1.4 \pm 0.4$ \\
\hline M+MUP & $131.2 \pm 0.2$ & $136.7 \pm 0.1$ & $142.7 \pm 1.2$ & $157.8 \pm 0.4$ & $1.2 \pm 0.5$ & $0.7 \pm 0.4$ & $0.8 \pm 0.7$ & $0.9 \pm 0.5$ \\
\hline C+MUP & $159.2 \pm 0.8$ & $147.7 \pm 0.4$ & $157.4 \pm 0.7$ & $168.7 \pm 0.2$ & $2.4 \pm 0.9$ & $0.8 \pm 0.4$ & $0.9 \pm 0.4$ & $1.7 \pm 0.3$ \\
\hline S+MUP & $137.8 \pm 0.5$ & $145.6 \pm 0.7$ & $154.8 \pm 0.5$ & $167.4 \pm 0.7$ & $1.7 \pm 0.4$ & $0.8 \pm 0.3$ & $0.9 \pm 0.5$ & $1.4 \pm 0.2$ \\
\hline $\mathrm{CC}+\mathrm{MUP}$ & $645.4 \pm 0.4$ & $639.1 \pm 0.8$ & $665.4 \pm 0.8$ & $721.4 \pm 0.6$ & $2.7 \pm 0.1$ & $3.9 \pm 0.6$ & $4.1 \pm 0.7$ & $4.4 \pm 0.3$ \\
\hline $\mathrm{W}+\mathrm{PP}$ & $653.8 \pm 0.3$ & $678.6 \pm 0.1$ & $697.9 \pm 0.5$ & $733.8 \pm 0.4$ & $3.8 \pm 0.3$ & $3.2 \pm 0.4$ & $3.6 \pm 0.1$ & $3.8 \pm 0.9$ \\
\hline $\mathrm{R}+\mathrm{PP}$ & $241.0 \pm 0.6$ & $229.8 \pm 0.9$ & $241.0 \pm 0.8$ & $273.8 \pm 0.9$ & $2.9 \pm 0.1$ & $2.0 \pm 0.8$ & $2.1 \pm 0.9$ & $2.8 \pm 0.2$ \\
\hline $\mathrm{M}+\mathrm{PP}$ & $189.4 \pm 0.5$ & $206.8 \pm 0.2$ & $226.5 \pm 0.6$ & $248.8 \pm 0.3$ & $2.4 \pm 0.3$ & $1.9 \pm 0.4$ & $2.0 \pm 0.6$ & $2.3 \pm 0.6$ \\
\hline $\mathrm{C}+\mathrm{PP}$ & $251.6 \pm 0.9$ & $289.6 \pm 0.7$ & $309.8 \pm 0.2$ & $347.4 \pm 0.1$ & $3.1 \pm 0.6$ & $2.6 \pm 0.7$ & $2.9 \pm 0.4$ & $3.1 \pm 0.5$ \\
\hline $\mathrm{S}+\mathrm{PP}$ & $237.4 \pm 0.3$ & $269.7 \pm 0.9$ & $293.6 \pm 0.4$ & $322.6 \pm 0.3$ & $2.2 \pm 0.4$ & $2.2 \pm 0.2$ & $2.4 \pm 0.4$ & $2.9 \pm 0.7$ \\
\hline $\mathrm{CC}+\mathrm{PP}$ & $1,347.2 \pm 0.7$ & $1,586.9 \pm 0.6$ & $1,795.4 \pm 0.4$ & $2,869.8 \pm 0.4$ & $4.9 \pm 0.1$ & $5.3 \pm 0.6$ & $5.8 \pm 0.5$ & $7.6 \pm 0.2$ \\
\hline $\mathrm{W}+\mathrm{MP}$ & $587.8 \pm 0.5$ & $616.9 \pm 0.4$ & $637.5 \pm 0.7$ & $686.9 \pm 0.2$ & $3.3 \pm 0.4$ & $3.5 \pm 0.8$ & $3.7 \pm 0.6$ & $3.8 \pm 0.4$ \\
\hline $\mathrm{R}+\mathrm{MP}$ & $262.4 \pm 0.9$ & $256.8 \pm 0.8$ & $279.7 \pm 1.5$ & $295.8 \pm 0.7$ & $2.4 \pm 0.3$ & $2.1 \pm 0.5$ & $2.2 \pm 0.7$ & $2.6 \pm 0.3$ \\
\hline $\mathrm{M}+\mathrm{MP}$ & $151.8 \pm 0.2$ & $144.6 \pm 0.4$ & $161.3 \pm 0.4$ & $193.8 \pm 0.4$ & $1.9 \pm 0.5$ & $0.7 \pm 0.1$ & $0.9 \pm 0.2$ & $1.0 \pm 0.3$ \\
\hline $\mathrm{C}+\mathrm{MP}$ & $209.1 \pm 0.4$ & $195.9 \pm 0.7$ & $217 \pm 0.9$ & $243.3 \pm 0.8$ & $2.3 \pm 0.7$ & $1.1 \pm 0.4$ & $1.9 \pm 0.5$ & $1.5 \pm 0.5$ \\
\hline $\mathrm{S}+\mathrm{MP}$ & $183.4 \pm 0.6$ & $183.4 \pm 0.6$ & $198.9 \pm 1.6$ & $223.8 \pm 0.6$ & $1.7 \pm 0.3$ & $1.0 \pm 0.1$ & $1.1 \pm 0.6$ & $1.3 \pm 0.1$ \\
\hline $\mathrm{CC}+\mathrm{MP}$ & $709.2 \pm 0.6$ & $730.6 \pm 0.3$ & $768.6 \pm 0.8$ & $794.7 \pm 0.9$ & $2.6 \pm 0.1$ & $3.7 \pm 0.4$ & $3.9 \pm 0.3$ & $4.1 \pm 0.6$ \\
\hline $\mathrm{W}+\mathrm{BP}$ & $542.1 \pm 0.9$ & $589.8 \pm 0.1$ & $609.6 \pm 0.4$ & $647.3 \pm 0.2$ & $2.9 \pm 0.5$ & $2.9 \pm 0.6$ & $3.1 \pm 0.3$ & $3.2 \pm 0.7$ \\
\hline $\mathrm{R}+\mathrm{BP}$ & $188.7 \pm 0.2$ & $198.7 \pm 0.4$ & $221.6 \pm 0.7$ & $267.5 \pm 0.8$ & $1.8 \pm 0.3$ & $1.2 \pm 0.3$ & $1.3 \pm 0.7$ & $1.7 \pm 0.2$ \\
\hline $\mathrm{M}+\mathrm{BP}$ & $131.8 \pm 0.7$ & $152.7 \pm 0.9$ & $171.5 \pm 0.1$ & $191.4 \pm 0.4$ & $1.5 \pm 0.5$ & $0.8 \pm 0.5$ & $0.9 \pm 0.8$ & $1.2 \pm 0.5$ \\
\hline $\mathrm{C}+\mathrm{BP}$ & $183.6 \pm 0.3$ & $196.7 \pm 0.6$ & $219.4 \pm 0.7$ & $238.7 \pm 0.2$ & $2.6 \pm 0.7$ & $1.1 \pm 0.1$ & $1.2 \pm 0.1$ & $1.9 \pm 0.3$ \\
\hline $\mathrm{S}+\mathrm{BP}$ & $163.9 \pm 0.6$ & $184.8 \pm 0.2$ & $198.8 \pm 0.4$ & $231.1 \pm 0.5$ & $1.2 \pm 0.3$ & $1.2 \pm 0.8$ & $1.3 \pm 0.2$ & $1.5 \pm 0.6$ \\
\hline $\mathrm{CC}+\mathrm{BP}$ & $644.7 \pm 0.7$ & $687.6 \pm 0.2$ & $710.7 \pm 0.8$ & $745.1 \pm 0.6$ & $2.3 \pm 0.4$ & $3.3 \pm 0.6$ & $3.5 \pm 0.5$ & $3.6 \pm 0.4$ \\
\hline
\end{tabular}

$W$ Wheat straw, $R$ rice straw, $M$ mustard straw, $C$ cotton straw, $S$ sorghum straw, $C C$ corn cobs, $M U P$ mausambi peel, $P P$ pineapple peel, $M P$ mango peel, $B P$ banana peel

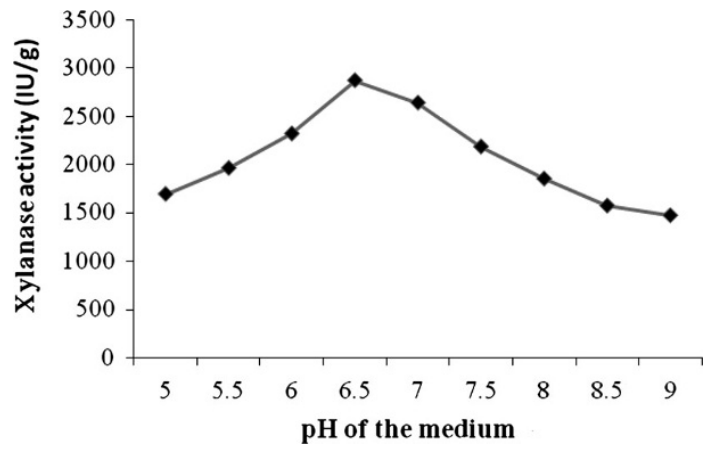

Fig. 2 Effect of $\mathrm{pH}$ on xylanase production in SSF

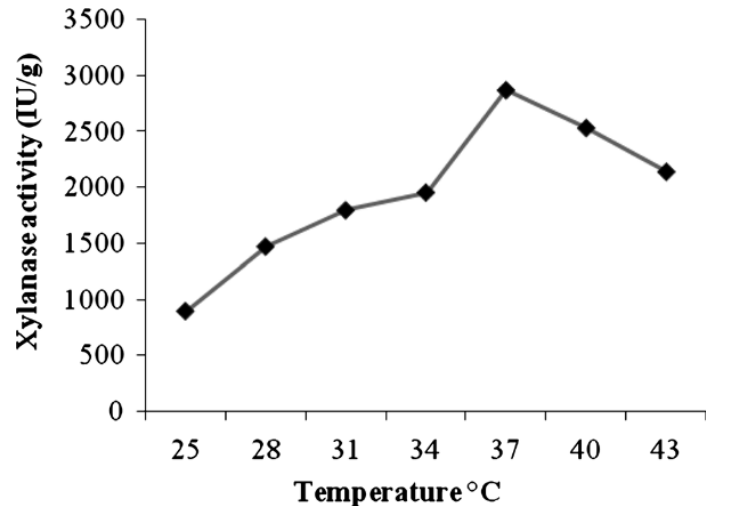

Fig. 3 Effect of temperature on xylanase production in SSF 
Fig. 4 The HPLC chromatogram showing the profile of hydrolysed products from corn cobs (Peak 1 xylose, Peak 2 xylobiose, Peak 3 xylotriose, Peak 4 xylotetraose, Peak 5 xylopentaose, Peak 6 xylohexaose)

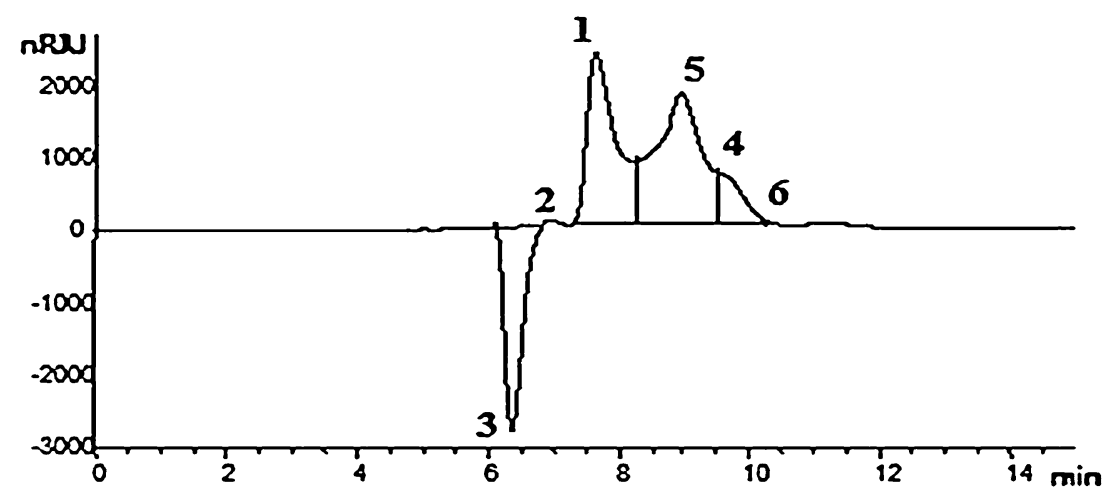

Table 5 Estimation of hydrolyzed products using HPLC from xylanase-treated biomass

\begin{tabular}{|c|c|c|c|c|c|c|c|c|c|c|c|c|}
\hline \multirow[t]{3}{*}{ Substrate $(\mathrm{g})$} & \multicolumn{12}{|c|}{ Concentration of sugars $(\mathrm{mg} / \mathrm{mL})$ at different time $(\mathrm{h})$ intervals } \\
\hline & \multicolumn{2}{|c|}{ Xylose } & \multicolumn{2}{|c|}{ Xylobiose } & \multicolumn{2}{|c|}{ Xylotriose } & \multicolumn{2}{|c|}{ Xylotetraose } & \multicolumn{2}{|c|}{ Xylopentaose } & \multicolumn{2}{|c|}{ Xylohexaose } \\
\hline & $4 \mathrm{~h}$ & $6 \mathrm{~h}$ & $4 \mathrm{~h}$ & $6 \mathrm{~h}$ & $4 \mathrm{~h}$ & $6 \mathrm{~h}$ & $4 \mathrm{~h}$ & $6 \mathrm{~h}$ & $4 \mathrm{~h}$ & $6 \mathrm{~h}$ & $4 \mathrm{~h}$ & $6 \mathrm{~h}$ \\
\hline W & 3.2 & 3.9 & 1.3 & 2.4 & 0.6 & 2.1 & 0.9 & 1.4 & 1.9 & 2.4 & 1.9 & 1.1 \\
\hline $\mathrm{R}$ & 1.5 & 2.7 & 1.4 & 2.1 & 0.5 & 0.9 & 0.2 & 1.2 & 1.9 & 2.4 & 1.2 & 0.8 \\
\hline M & 1.2 & 2.2 & 1.2 & 1.7 & 0.8 & 1.4 & 0.3 & 0.6 & 1.3 & 1.7 & 0.6 & 0.3 \\
\hline C & 0.6 & 1.6 & 0.9 & 1.2 & 0.5 & 1.3 & 0.4 & 0.5 & 0.9 & 1.1 & 0.7 & 0.2 \\
\hline S & 0.4 & 1.1 & 0.4 & 0.7 & 0.1 & 0.9 & 0.3 & 1.0 & 1.6 & 1.9 & 1.8 & 0.7 \\
\hline $\mathrm{CC}$ & 4.2 & 6.8 & 2.6 & 3.7 & 1.8 & 2.6 & 1.2 & 3.1 & 3.8 & 4.2 & 2.8 & 1.4 \\
\hline
\end{tabular}

$W$ Wheat straw, $R$ rice straw, $M$ mustard straw, $C$ cotton straw, $S$ sorghum straw, $C C$ corn cobs

Hydrolysis of pretreated biomass by xylanase

Kambourova et al. (2006) performed xylanase from Anoxybacillus flavithermus BC treated oat spelt, birch wood and beech wood xylan as substrate and the main sugar was xylose. In this direction, the pretreated biomass was reacted with $T$. koeningi xylanase for different incubation periods $(2,4,6$ and $8 \mathrm{~h})$ at $14 \mathrm{U}$ enzyme dose and obtained the xylose and xylo-oligosaccharides. Figure 4 illustrates the xylo-oligosaccharides profile (Peak $1=$ xylose; Peak 2 = xylobiose; Peak $3=$ xylotriose, Peak $4=$ xylotetraose, Peak $5=$ xylopentaose, Peak $6=$ xylohexaose) of pretreated corn cobs and Table 5 clearly shows the released hydrolysates of pretreated biomass quantitatively by HPLC. In the 4 and $6 \mathrm{~h}$ incubation maximum xylose, xylobiose xylotriose and xylohexaose was observed, but in the $6 \mathrm{~h}$ and beyond, there was constant amount of xylose due to insufficient or incomplete hydrolysis of substrate. In case of xylotetraose and xylopentaose, they increased in pretreated corn cobs from 4 to $6 \mathrm{~h}$. Alkali pretreated wheat straw was saccharified using xylanase alone or mixture of FPase and $\beta$ glucosidase at $6 \mathrm{~h}$ increased the reducing sugars (Kumar et al. 2013). The use of agro-wastes in the production of enzymes such as xylanase and valuable products is costeffective, at the same time reduces the environmental pollution due to the dumping of such wastes.

\section{Conclusion}

The present work demonstrated that the alkaline pretreatment method could significantly alter the physico-chemical structure of the substrates. The pretreated substrate composition clearly states that the cellulose content was increased but hemicellulose and lignin contents were decreased. The FT-IR data shows the depolymerization of pretreated corn cobs, which was easily utilized by the fungus. The untreated agro-residue yielded lesser xylanase than the pretreated agro-residue. Besides, the pretreated substrates combined with the fruit peels enhanced the xylanase production by SSF. The isolated T. koeningi xylanase degraded the pretreated biomass and the resultant hydrolysed products were quantified using HPLC. The results are encouraging from the point of view of obtaining cheap source of xylanase from agro-residues and their application in converting hemicellulose to fermentable sugars for commercial application.

Acknowledgments We are thankful to Dr. S.C. Basappa, former Deputy Director and Scientist, Central Food Technological Research Institute (CFTRI), Mysore, for his encouragement and critical comments on the manuscript.

Conflict of interest All the three authors declare that they have no conflict of interest. 
Open Access This article is distributed under the terms of the Creative Commons Attribution License which permits any use, distribution, and reproduction in any medium, provided the original author(s) and the source are credited.

\section{References}

AOAC (2005) Official methods of analysis. 18th edn.: p 47

Bailey MJ, Biely P, Poutanen K (1992) Interlaboratory testing of methods for assay of xylanase activity. J Biotechnol 23:257-270

Bedford MR, Classen HL (1992) The influence of dietary xylanase on intestinal viscosity and molecular weight distribution of carbohydrates in rye-feed broiler chick. In: Visser J, Beldman G, Kusters-Van Someren MA, Voragen (eds) Xylans and xylanase, pp 361-370. Elsevier, Amsterdam

Berghem LER, Petterson LG (1973) Mechanism of enzymatic cellulose degradation and purification of a cellulolytic enzyme from Trichoderma viride active on highly ordered cellulose. In J Biochem 37:21-30

Biely P (1985) Microbial xylanolytic systems. Trends Biotechnol 3:286-290

Bocchini DA, Damiano VB, Gomes E, Da Silva R (2003) Effect of Bacillus circulans D1 thermostable xylanase on biobleaching of eucalyptus Kraft pulp. Appl Biochem Biotechnol 105(10):393-402

Carpita N, Mc Cann M (2000) The cell wall. In: Buchanan BB, Gruissem W, Jones RL (eds) Biochemistry and molecular biology of plants. American society of plant physiologists, Rockville, pp 52-108

Chen S, Wyman M (1991) Cellulase production induced by carbon sources derived from waste newspaper. Process Biochem 26:93-100

Dhillon A, Gupta JK, Jauhari BM, Khanna SA (2000) Cellulase-poor, thermostable, alkalitolerant xylanase produced by Bacillus circulans $\mathrm{AB} 16$ grown on rice straw and its application in biobleaching of eucalyptus pulp. Bioresour Technol 73:273-277

Ding TY, Hii SL, Ong LGA (2012) Comparison of pretreatment strategies for conversion of coconut husk fiber to fermentable sugars. Bioresour Technol 7:1540-1547

Dubois M, Gilles KA, Hamilton JK, Rebers PA, Smith F (1956) Colorimetric method for determination of sugars and related substances. Anal Chem 26:350

Frazier WC, Westhoff DC (2008) Food microbiology. McGraw Hill Companies, New Delhi

Gomes I, Gomes J, Steines W, Esterbaner H (1992) Production of cellulase and xylanase by a wild strain of Trichoderma viride. Appl Microbiol Biotechnol 36:701-707

Gupta VK, Gaur R, Gautam N, Kumar P, Yadav IJ, Darmwal NS (2009) Optimization of xylanase production from Fusarium solani F7. Am J Food Technol 4:20-29

Jung HJ, Vogel KP (1992) Lignification of switch grass (Panicum virgatum) and big bluestem (Andropogon gerardii) plant part during maturation and its effect on fiber degradability. J Sci Food Agri 59:166-176

Kambourova M, Mandeva R, Fiume I, Maurelli L, Rossi M, Morana A (2006) Hydrolysis of xylan at high temperature by co-action of the xylanase from Anoxybacillus flavithermus BC and the $\beta$ xylosidase and $\alpha$ - arabinosidase from Sulfolobus solfataricus. J Appl Micobiol 102:1586-1593

Kapoor M, Beg QK, Bhushan B, Singh K, Dadhich KS, Hoondal GS (2001) Application of an alkaline and thermostable polygalacturonase from Bacillus sp. MG-2 in degumming of ramie
(Boehmeria nivea) and sunn hemp (Crotalaria juncea) bast fibers. Process Biochem 36:803-807

Kaushal R, Sharma N, Tandon D (2012) Cellulase and xylanase production by co-culture of Aspergillus niger and Fusarium oxysporum utilizing forest waste. Turk J Biochem 37:35-41

Khabarov YG, Kamakina ND, Gusakov LV, Veshnya-kov VA (2006) New spectrophotometric method for determination of furfural and pentoses. Russ J Appl Chem 79:103-106

Kim TB, Oh DK (2003) Xylitol production by Candida tropicalis in a chemically defined medium. Biotechnol Lett 25:2085-2088

Kleinert M, Barth T (2008) Phenols from lignin. Chem Eng Technol 31:736-745

Kumar R, Mago G, Balan V, Wyman CE (2009) Physical and chemical characterization of corn stover and poplar solids resulting from leading pretreatment technologies. Bioresour Technol 100:3948-3962

Kumar L, Kumar D, Nagar S, Gupta R, Garg N, Kuhad RC, Gupta VK (2013) Modulation of xylanase production from alkaliphilic Bacillus pumilus VLK-1 through process optimization and temperature shift operation. 3 Biotech. doi:10.1007/s13205013-0160-2

Li K, Fu S, Zhan H, Zhan Y, Lucia LA (2010) Analysis of the chemical composition and morphological structure of banana pseudo-stem. Bioresour Technol 5:576-585

Liang CY, Marchessault RH (1959) Infrared spectra of cellulose, hemicelluloses and lignin of natural fibers. J Polym Sci 39:269-278

Lowry OH, Rosbrough NJ, Farr AL, Randall RJ (1951) Protein measurement with the folin phenol reagent. J Biol Chem 193:257-432

Miller GL (1959) Use of dinitrosalicylic acid reagent for determination of reducing sugar. Anal Chem 313:426-428

Mosier N, Wyman C, Dale B, Elander R, Lee YY, Holtzapple M, Ladisch M (2005) Features of promising technologies for pretreatment of lignocellulosic biomass. Bioresour Technol 96:673-686

Owen NL, Thomas DW (1989) Infrared studies of hard and soft woods. Appl Spectrosc 43:451-455

Rajaram S, Varma A (1990) Production and characterization of xylanase from Bacillus thermoalkalophilus grown on agricultural wastes. Appl Microbiol Biotechnol 34:141-144

Reddy GV, Babu PR, Komaraih P, Roy KRRM, Kothari IL (2003) Utilization of banana waste for the production of lignolytic and cellulolytic enzymes by solid substrate fermentation using two Pleurotus ostreatus and Pleurotus sajorcaju. Process Biochem 381:457-1462

Reese ET, Mandles M (1963) Enzymatic hydrolysis of cellulose and its derivatives. In: Methods Carbohydrate Chemistry 3rd edn. London, pp 139-143

Richard WC (2002) Method of treating lignocellulosic biomass to produce cellulose. http://ip.com.patent/US6419788

Robert P, Marquis V, Barron C, Guillon F, Saulnier L (2005) FT-IR investigation of cell wall polysaccharides from cereal grains. Arabinoxylan infrared assignment. J Agri Food Chem 53:7014-7018

Schulz H, Baranska M (2007) Identification and quantification of valuable plant substances by IR and Raman spectroscopy. Vib Spectrosc 43:13-25

Shi J, Li J (2012) Metabolites and chemical group changes in the wood forming tissue of Pinus koraiensis under inclined condition. Bioresour Technol 7:3463-3475

Singh R, Singh S, Trimukhe KD, Pandare KV, Bastawade KB, Gokhale DV, Varma AJ (2005) Lignin-carbohydrate complexes from sugarcane bagasse: Preparation purification and characterization. Carbohydr Polym 62:57-66 
Soto ML, Nunez MJ, Lema J (1994) Enzymatic saccharification of alkali-treated sun flower hulls. Bioresour Technol 9:49-53

Sun Y, Cheng J (2002) Dilute acid pretreatment of rye straw and Bermuda grass for ethanol production. Bioresour Technol 83:1-11

Sun XF, Xu F, Sun RC, Fowler P, Baird MS (2005) Characteristics of degraded cellulose obtained from steam exploded wheat straw. Carbohydr Res 340:97-106

Villas-Boas SG, Esposito E, Mendonc MM (2000) Novel lignocellulolytic ability of Candida utilis during solid-substrate cultivation on apple pomace. World J Microb Biot 14:38-42
Wilson RH, Smith AC, Kacurakova M, Saunders PK, Wellner N, Waldron KW (2000) Plant Physiol 124:397-405

Wong KKY, Tan LUL, Saddler JN (1988) Multiplicity of $\beta-1,4-$ xylanases in microorganisms: functions and applications. Microbiol Rev 52:305-317

Yu P, Block H, Niu Z, Doiron K (2007) Rapid characterization of molecular chemistry, nutrient make up and micro location of internal seed tissue. J Synchrotron Radiat 14:382-390 